\title{
SUPPORTING ENGINEERING STUDENTS ON ACADEMIC PROBATION BY IMPROVING THEIR LEARNING SKILLS
}

\author{
Valerie Bourassa and Maria Orjuela-Laverde \\ Faculty of Engineering, McGill University, Montreal, QC Canada \\ valerie.bourassa@mail.mcgill.ca
}

\begin{abstract}
This paper presents the experience of creating a student task force to support undergraduate engineering students on academic probation by strengthening their learning skills. The program described in the paper was designed based on the work of Professor Saundra Yancy McGuire, expert in the field of supporting student learning for over forty years. One of Professor McGuire's main statement is the need to develop metacognitive skills among our student population [1]. Metacognition as a construct is frequently associated with John Flavell (1979) who defined it as "the ability to: think about one's own thinking; be consciously aware of oneself as a problem solver; monitor, plan, and control one's mental processing; and, accurately judge one's level of learning", [2]. McGill's ELATE (Enhancing Learning and Teaching in Engineering) initiative designed and implemented a program where students on academic probation meet in small groups on a weekly basis to receive support on the learning skills they struggle the most. Weekly meetings were conducted by engineering Graduate Students Instructors (GSIs) who received an intensive training on metacognition, growth mindset and learning skills. This project having completed the training phase with GSIs and Peer Tutors, we present in this paper survey data that describe challenges and benefits on initiating a project of this nature.
\end{abstract}

Keywords: Students as partners; growth mindset; mentorship; self-efficacy.

\section{INTRODUCTION}

Universally, undergraduate students from all disciplines face challenges to meet the academic requirements of their studies. Failure rates above the desired rates are, however, an indicator that students enter their university program poorly equipped with the learning skills necessary for academic success. Although many universities aim at ameliorating the quality of higher education at their institution, only a few have dedicated resources in encouraging students on probation, or at risk of failing out of their program, to take charge of their own learning experience. The Enhancing Learning and Teaching in Engineering (ELATE) program at McGill University developed an initiative to address this issue on multiple levels. This initiative aims to 1) teach and equip undergraduate students in need with metacognitive study strategies that foster academic success, as well as providing subject matter peer-tutoring, and 2) train STEM graduate students instructors and engineering peer-tutors in accommodating their teaching approaches to facilitate these study strategies in their students. These strategies include reflecting on reading, note-taking, organizing materials, memorizing, test-taking, and writing habits to encourage students to become more active learners.

We are using three constructs to guide this study: (1) self-efficacy; (2) growth mindset, and (3) students as partners. Self-efficacy is first introduced as a construct in Bandura's seminal publication 'Social foundation of thought and action: a social cognitive theory' [3]. The author defines Self-Efficacy as "People's judgements of their capabilities to organize and execute courses of action required to attain designated types of performances". Selfefficacy is task-defined and in this current study we are assessing Graduate Student Instructors (GSIs) and PeerTutors' (PTs) perceived self-efficacy regarding mentoring undergraduate students in improving their learning skills. The second construct used to design the program was Dweck's Growth Mindset theory (2006) where the author centers her work under the premise that intelligence and learning can be developed and improved as opposed to levels of intelligence being fixed traits [4]. Until the late 70's and early 80's, it was believed that the brain was unmalleable; therefore skills, talent and intelligence were predetermined when the person was born $[5,6]$. Most notably, Dweck's work has challenged this premise of a fixed mindset. Lastly, the third construct guiding ELATE's academic skills intervention, and the construct we will most explore in this paper, is the Student as Partners model (SaP). This model supports students and faculty/academic staff working together, as partners, to enhance teaching and learning experiences [7]. In the ELATE initiative presented here, $\mathrm{SaP}$ is used as the mechanism to improve academic skills through a mentoring structure involving graduate students, staff, and undergraduate students. This project 
also builds on the work conducted by the Project Information Literacy initiative where one of the main premises of this study is the use of peer-to-peer learning to nurture personal agency and advance campus-wide learning [8].

\section{PROGRAM OVERVIEW}

\subsection{Students on Probation}

Multiple factors can affect and contribute to a student's trajectory into academic probation. Those include but are not limited to physical or mental health, socio-economic status, gender, etc [9-11]. Once students find themselves failing their courses, it is important to identify the challenges in the learning behaviors that contribute to these academic difficulties. The initiative described here attempts to create an inclusive learning environment by resolving poor study behaviors in and out of the classroom.

Over 200 undergraduate students in the Faculty of Engineering at McGill University receive a cumulative grade-point average (cGPA) of less than 2.0 every year. These students were offered the opportunity to enroll in this program. Upon enrollment, students completed the Learning and Study Skills Inventory (LASSI) to determine if they would benefit most from training in wellness and coping, or successful study behaviors, or both. Completion of LASSI assessment is currently mandatory for students on probation to apply for readmission at Concordia University [12], which greatly inspired this initiative at McGill.

Students whose LASSI score indicated that they would benefit from improving their study skills were assigned to a Graduate Student Instructor (GSI) for the duration of the semester. In these sessions, GSIs lead small-group workshops covering successful studying strategies that will help students to remember and understand information in ways that will reflect in various types of assessments. These strategies tackle various aspects of the academic work such as the growth mindset, the study cycle, time management and goal-setting, note-taking, organizing materials, rehearsing and memorizing, test-taking, reading, and writing.

These 1-hour weekly sessions were offered for a span of 8 weeks. Small group assignments represent a critical aspect of this program (4-10 students per group). Indeed, team-building exercises build trust, and promote healthy conversations. We believe that this type of environment encourages accountability in our population of students on probation by allowing them to connect with peers with whom they will be meeting weekly. In addition, these sessions are highly personalized; participating students are encouraged to bring the syllabi of all their courses to their GSI in order to develop strategies that suit their schedule best.

At the start of the program, students on probation completed a series of assessments to determine their initial mindset and perspective regarding their studying strategies. These assessments will also be administered at the end of the program for pre-post analysis. The assessments used are:

1. The Saundra Y. McGuire Learning Strategies Inventory [1]: This inventory lists behaviors that you should exhibit in order to excel any given course.

2. The New General Self-Efficacy Scale [13]: Selfefficacy is commonly defined as a student's beliefs in their own abilities and confidence.

3. A mindset questionnaire adapted from PERTS (Project for Education Research that Scales): This questionnaire provides insight on whether the intervention promoted a mindset switch in students on probation.

\subsection{Graduate Student Instructors}

Working with graduate students with the aim of improving teaching and learning at the department level has proven to be an incredibly effective strategy in the short and long term. In the short term, graduate students are enthusiastic, opened to learning new skills, provide enormous support to instructors, and have the advantage of having completed their undergraduate degree in the recent past. They possess a perspective of their own learning experience that sometimes evade the course instructors and can therefore identify aspects of courses that can be improved for current students. From a long-term perspective, graduate students involved in pedagogical projects during their graduate studies bring with them excellent background in teaching and learning skills once they are hired for academic positions.

Graduate Students in the Faculty of Engineering at McGill University with substantial teaching experience were recruited as Graduate Student Instructors (GSIs) for this program. GSIs received over 14 hours of training on facilitation and successful study skills by learning specialists. The description of these training sessions is outlined in Table 1. The format of the training program was inspired by the University Skills curriculum at Concordia University, Montreal, QC.

Table 1: Training sessions designed for Graduate Students Instructors and Peer Tutors participating in the program. These sessions offer facilitation training with the aim of creating collaborative workspace, as well as content material on effective study skills.

\begin{tabular}{|l|l|l|}
\hline $\begin{array}{c}\text { Training } \\
\text { Type }\end{array}$ & \multicolumn{1}{|c|}{ Topic } & \multicolumn{1}{c|}{ Description } \\
\hline Facilitation & $\begin{array}{l}\text { The Growth } \\
\text { Mindset } \\
(2 \mathrm{~h})\end{array}$ & $\begin{array}{l}\text { Participants will explore } \\
\text { the relationship between } \\
\text { study behaviors and }\end{array}$ \\
\hline
\end{tabular}




\begin{tabular}{|c|c|c|}
\hline & & $\begin{array}{l}\text { academic performance. } \\
\text { They will identify growth } \\
\text { mindset behaviors that } \\
\text { contribute to success, and } \\
\text { how they can promote } \\
\text { mindset switch in their } \\
\text { own teaching. }\end{array}$ \\
\hline $\begin{array}{l}\text { Study } \\
\text { Strategies }\end{array}$ & $\begin{array}{l}\text { The Study } \\
\text { Cycle } \\
\text { (1h) }\end{array}$ & $\begin{array}{l}\text { Participants will learn to } \\
\text { apply the basic principles } \\
\text { of a Study Cycle } \\
\text { throughout the semester } \\
\text { to attain their academic } \\
\text { objectives. }\end{array}$ \\
\hline $\begin{array}{l}\text { Study } \\
\text { Strategies }\end{array}$ & $\begin{array}{l}\text { Time } \\
\text { Management } \\
\text { \& Goal Se- } \\
\text { tting } \\
\text { (1h) }\end{array}$ & $\begin{array}{l}\text { Participants will learn } \\
\text { principles of how to set, } \\
\text { maintain, and achieve } \\
\text { academic goals while } \\
\text { keeping a healthy student- } \\
\text { life balance. }\end{array}$ \\
\hline $\begin{array}{l}\text { Study } \\
\text { Strategies }\end{array}$ & $\begin{array}{l}\text { Note-taking } \\
\& \\
\text { Organizing } \\
\text { Materials } \\
\text { (1h) }\end{array}$ & $\begin{array}{l}\text { Strategies to summarize } \\
\text { concepts during knowledge } \\
\text { acquisition. Through } \\
\text { concept mapping students } \\
\text { will learn to analyze and } \\
\text { evaluate relationships } \\
\text { between concepts. } \\
\text { Strategies will also address } \\
\text { different types of } \\
\text { notetaking systems that can } \\
\text { be adjusted for studying or } \\
\text { taking notes in class. }\end{array}$ \\
\hline $\begin{array}{l}\text { Study } \\
\text { Strategies }\end{array}$ & $\begin{array}{l}\text { Rehearsing } \\
\& \\
\text { Memorizing } \\
\text { (1h) }\end{array}$ & $\begin{array}{l}\text { Students will learn di- } \\
\text { fferent methods to } \\
\text { remember information in } \\
\text { logical ways using their } \\
\text { concept maps, amongst } \\
\text { other strategies. Students } \\
\text { will be able to identify } \\
\text { what strategies } \\
\text { best allow them to attain } \\
\text { their academic objectives, } \\
\text { depending on course } \\
\text { content. }\end{array}$ \\
\hline $\begin{array}{l}\text { Study } \\
\text { Strategies }\end{array}$ & $\begin{array}{l}\text { Test-Taking } \\
\text { (1h) }\end{array}$ & $\begin{array}{l}\text { Students will be able to } \\
\text { learn different strategies } \\
\text { that are crucial in leading } \\
\text { up to an exam in order to } \\
\text { be able to manage } \\
\text { hindering stress related to } \\
\text { test-taking. Students will } \\
\text { also learn tips for time- } \\
\text { management, prioritizing } \\
\text { questions during exams, } \\
\text { and post-exam reflections. }\end{array}$ \\
\hline $\begin{array}{l}\text { Study } \\
\text { Strategies }\end{array}$ & $\begin{array}{l}\text { Reading \& } \\
\text { Writing }\end{array}$ & $\begin{array}{l}\text { Approaches for students to } \\
\text { read and write effectively. }\end{array}$ \\
\hline
\end{tabular}

\begin{tabular}{|c|c|c|}
\hline & (1h) & $\begin{array}{l}\text { Students will learn e- } \\
\text { ffective ways to outline } \\
\text { their ideas for short and } \\
\text { long answer essays and } \\
\text { emphasize } \\
\text { hypothesis/stance } \\
\text { statements. Strategies to } \\
\text { avoid "blank-page } \\
\text { syndrome" and strategies } \\
\text { to retain important } \\
\text { information through } \\
\text { identification of key words } \\
\text { in written materials will } \\
\text { also be discussed. }\end{array}$ \\
\hline Facilitation & $\begin{array}{l}\text { Designing a } \\
\text { Collaborative } \\
\text { Space }(3 \mathrm{~h})\end{array}$ & $\begin{array}{l}\text { Participants will explore } \\
\text { ways to design safe spaces } \\
\text { for group activities. }\end{array}$ \\
\hline Facilitation & $\begin{array}{l}\text { Revisited } \\
(3 \mathrm{~h})\end{array}$ & $\begin{array}{l}\text { Mid-semester, participants } \\
\text { reunite to share their } \\
\text { experience leading their } \\
\text { small-group sessions. }\end{array}$ \\
\hline
\end{tabular}

\subsection{Peer Tutors}

In the university-setting, teaching takes place at various levels: Professors and teaching assistants use their expertise and experience to transfer knowledge through lectures and laboratories, and, most importantly, teaching and learning occurs outside of the classroom in the form of discussions and debate between peers. This form of teaching, called peer-mentoring, is believed to have a greater impact on student learning than traditional classroom teaching [14].

At McGill University, the Faculty of Engineering offers the possibility to excelling students to be hired as peertutors. This service is called the Engineering Peer-Tutoring Services (EPTS). Through EPTS, Peer-Tutors (PTs) are provided with a space to offer their current peers with content-specific help for specific courses. Although this service is used by nearly 600 undergraduate students yearly, the current format of EPTS has some limitations. Namely, students who are recruited to become PTs receive no formal teaching training due to the limited work hours of their contract. This is particularly important as, although PTs have known sustained success in their studies at McGill, they may not possess the metacognitive tools to identify studying habits that have contributed to their success. One objective of this initiative was to provide an opportunity for PTs to reflect on their own study habits and understand how effective study behaviors impact academic performance.

Similarly to the GSIs, PTs received a portion of training on facilitation and study skills described in Table 1. Due to their own academic demands, we reduced the load of mandatory training of PTs to 8 hours, including the Growth 
Mindset and Facilitation workshops, plus 3 Study Strategies workshops of their choice.

\section{RESULTS AND PROGRAM EVALUATION}

The pilot version of this program is currently underway. Although we are actively collecting data from the cohort of students on probation participating in this program, this paper focuses on the training feedback we received from our GSI and PT task force. Of interest, we were curious to see the GSIs and PTs' own assessment of their teaching abilities after having received the training. This is important as it is one way to evaluate the validity of the training they received prior to welcoming their students on probation. To do this, our group adapted the Ralf Schwarzer, Gerdamarie S. Schmitz, \& Gary T. Daytner teaching self-efficacy questionnaire [15] to mentoring. The following 9 statements were rated on a likert scale ranging from Strongly Disagree to Strongly Agree:

1. I am convinced that I can successfully teach all relevant subject content (Study Strategies).

2. I know that I can maintain a positive relationship with students, even when tensions arise.

3. When I try hard, I feel that I can reach even the most difficult students.

4. I am convinced that, as time goes by, I will continue to become more and more capable of helping to address my mentees' needs.

5. Even if I get disrupted while mentoring, I am confident that I can maintain my composure and continue to help.

6. I am confident in my ability to be responsive to my mentees' needs even if I am having a bad day.

7. If I try hard enough, I know that I can exert a positive influence on both the personal and academic development of my students.

8. I am convinced that I can develop creative ways to manage my own academic schedule and continue to mentor well in the ELATE Student Success program.

9. I know that I can continue carrying out new commitments even though I am involved in mentoring.

The results of the mentoring self-efficacy questionnaire are shown in Figure 1.

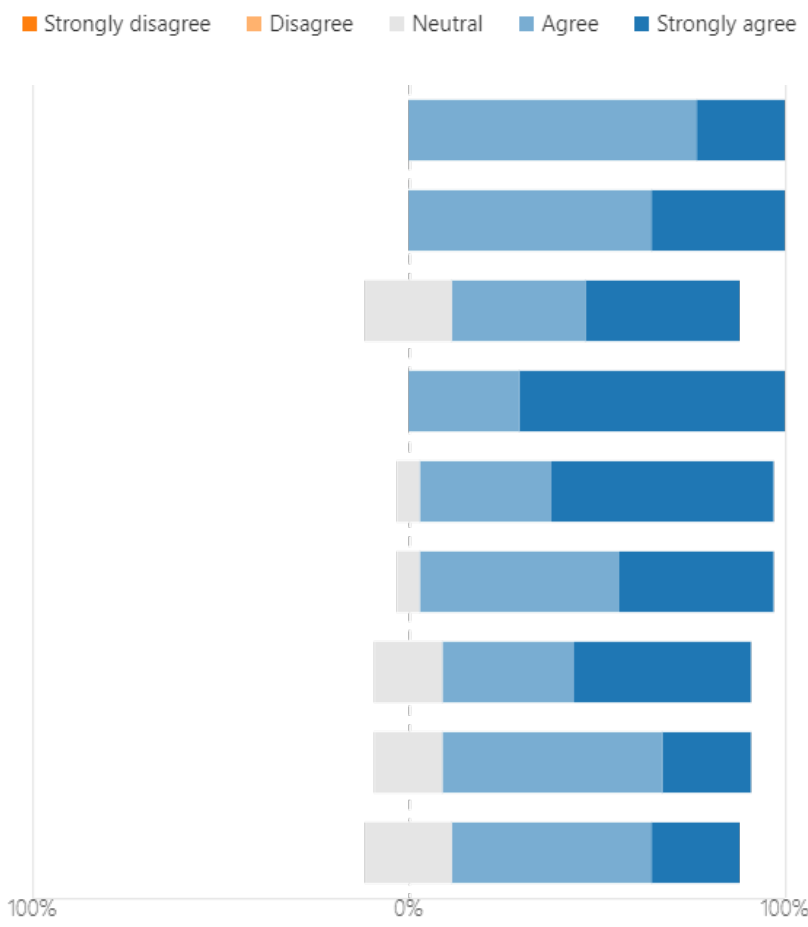

Figure 1: Likert scale Mentoring Self-Efficacy questionnaire administered to GSIs and PTs $(n=17)$. Y-axis represents each question from \#1 (top) to \#9 (bottom) in order listed above.

In addition to assessing the GSIs and PTs on their perceived teaching abilities, we asked them to provide feedback on the training portion of the program by rating the following questions:

1. Overall the workshops lived up to my expectations

2. In the future, I will use what I learned

3. Overall, I would recommend these workshops to my colleagues

The results are shown in Figure 2 for the six Study Strategies modules (A), the Facilitation: Designing a Collaborative Space workshop (B), and the Facilitation: Growth Mindset workshop (C).

Importantly, we will also offer the opportunity to GSIs and PTs to provide feedback, as well as rate their teaching self-efficacy after having completed their work with their cohort of students. These may yield interesting insights on the relationship between selfassessed teaching proficiency and actual teaching proficiency. 


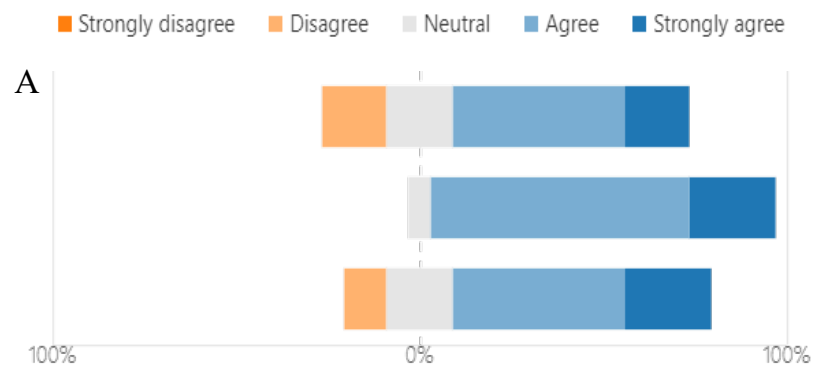

B
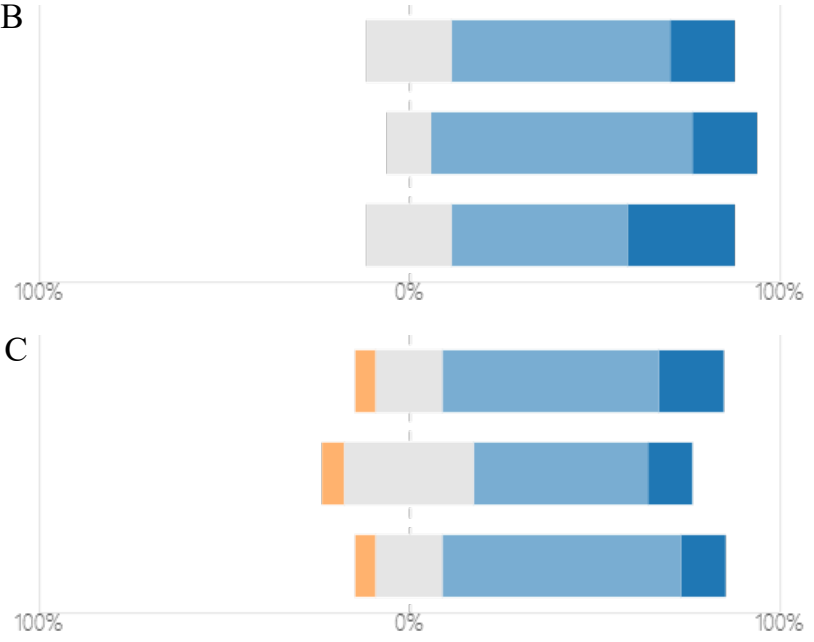

\section{DISCUSSION}

The pilot version of this program is currently underway, and we do not possess enough data yet to evaluate its success for the students on probation. Parameters that will be of interest once the program has finished will be: ratio of students on academic probation who come off academic probation as a result of enrollment in this program, how long it takes for each student in the program to get off academic probation, tracking performance levels in courses (cGPA, aGPA), and graduation time.

However, evaluations of the training component of the program showed that Graduate Student Instructors and

\section{REFERENCES}

1. McGuire, S.Y., Teach Students How to Learn: Strategies You Can Incorporate Into Any Course to Improve Student Metacognition, Study Skills, and Motivation. 2015: Stylus Publishing.

2. McGuire, S., Metacognition: The Key to Teaching Students Transformative Learning Strategies. 2016, Center for the Enhancement of Learning and Teaching (CELT): University of Kentucky.
Figure 2: Likert scale for workshop feedback questions administered to GSIs and PTs $(n=17)$. Y-axis represents each question from \#1 (top) to \#3 (bottom) in order listed above.

Peer Tutors feel very confident in their abilities to mentor fellow students and believe that they can exert a positive impact on the personal and academic development of their peers (Figure 1.). Further assessment showed that the training sessions including the Study Strategies modules (A), the Facilitation: Designing a Collaborative Workspace workshop (B), and Facilitation: Growth Mindset workshop (C) were received very positively by the majority of our participants (Figure 2.).

"Great pilt project overall! The study modules were extremely pplicable to peer tutors as well as graduate students, but I hope future programs would help incorporate more methods of how to teach technical knowledge to struggling students as well. These sessions were very well organized, and all the effort and hard work put into them was more than evident!"

- Anonymous

Based on this feedback, we are excited to learn and adapt from the needs and suggestions of all individuals involved in teaching and learning, including the GSIs and PTs.

Prior to this initiative, McGill University possessed no system in place to assist and rehabilitate students on academic probation. ELATE is the first initiative to implement such a structure and does so by relying profoundly on the principle of the student-as-partners model. Constructive support from peers facilitate a partnership build around respect, reciprocity and shared responsibility in learning [16], which we believe has tremendous prospect in assisting student populations in need.

Multiple factors, however, can be responsible for student's trajectory into academic probation. To address, this, we are developing a sister program that will help students develop flexibility, endurance, resilience, and above all, balance in their lives.

3. Bandura, A., Social foundations of thought and action: A social cognitive theory. Social foundations of thought and action: A social cognitive theory. 1986, Englewood Cliffs, NJ, US: Prentice-Hall, Inc. xiii, 617-xiii, 617.

4. Dweck, C.S., Mindset: The new psychology of success. 2008: Random House Digital, Inc.

5. Smith, J.K., Brown, P.C., Roediger III, H.L., \& McDaniel, M.A. (2014). Make It Stick. The 
Science of Successful Learning. The Journal of Educational Research, 2015. 108(4): p. 346-346.

6. Fuchs, E. and G. Flügge, Adult neuroplasticity: more than 40 years of research. Neural plasticity, 2014. 2014.

7. Mercer-Mapstone, L., et al., A systematic literature review of students as partners in higher education. International Journal for Students as Partners, 2017. 1(1).

8. Head, A.J.F., Barbara; MacMillan, Margy. Information literacy in the age of algorithms. 2020; Available from: https://www.projectinfolit.org/uploads/2/7/5/4/27 541717/algoreport.pdf.

9. Colleen Anne, D., et al., PAWSing Student Stress: A Pilot Evaluation Study of the St. John Ambulance Therapy Dog Program on Three University Campuses in Canada. Canadian Journal of Counselling and Psychotherapy, 2015. 49(4).

10. Natalie, D.-B., et al., Investigating Stress, Psychological Well-Being, Mental Health Functioning, and Self-Regulation Capacity Among University Undergraduate Students: Is
This Population Optimally Functioning? Canadian Journal of Counselling and Psychotherapy, 2015. 49(3).

11. Quebec Student Union. 2019; Available from: https:/unionetudiante.ca/documents-andpublications/.

12. Concordia University, Readmission Requirements. Available from: https://www.concordia.ca/students/success/stude nts-in-failed-standing/readmissionrequirements.html\#step2.

13. Chen, G., S.M. Gully, and D. Eden, Validation of a New General Self-Efficacy Scale. Organizational Research Methods, 2001. 4(1): p. 62-83.

14. Goodlad, S., Mentoring and tutoring by students. 2013: Routledge.

15. Schwarzer, R.S., Gerdamarie S.; Daytner, \& Gary T., The Teacher Self-Efficay Scale. 1999.

16. Bovill, C., A. Cook-Sather, and P. Felten, Students as co-creators of teaching approaches, course design, and curricula: implications for academic developers. International Journal for Academic Development, 2011. 16(2): p. 133-145. 